\title{
Pendampingan Pembuatan dan Penerapan Alat Peraga Matematika bagi Guru SD Gugus II Kecamatan Amanuban Barat
}

\author{
Prida N. L. Taneo', Farida Daniel ${ }^{2}$, Yusak I. Bien ${ }^{3}$ \\ ${ }^{1,2,3}$ Program Studi Pendidikan Matematika, STKIP Soe Timor Tengah Selatan, NTT \\ ${ }^{1}$ stafpridataneo@stkipsoe.ac.id \\ ${ }^{2}$ staffaridaniel@stkipsoe.ac.id \\ ${ }^{3}$ stafyusakbien@stkipsoe.ac.id
}

\begin{abstract}
ABSTRAK
Hasil analisis situasi sehubungan dengan pembelajaran matematika di 2 sekolah mitra yang ada di gugus II kecamatan Amanuban Barat yaitu SD Inpres Oenali dan SD Inpres Oefatu menunjukkan pelaksanaan pembelajaran matematika yang abstrak dan berpaku pada buku teks saja, keberadaan alat peraga matematika sangat minim, kemampuan guru dalam pembuatan alat peraga matematika masih kurang, pertemuan KKG dan pelatihan-pelatihan tingkat kabupaten lebih diarahkan pada kegiatan pembuatan administrasi pembelajaran dan belum menyentuh pada esensi dari pembelajaran matematika seperti desain alat peraga. Solusi dari permasalahan ini adalah transfer ipteks bagi guru-guru berupa pendampingan pembuatan dan penerapan alat peraga matematika. Metode pelaksanaan kegiatan ini berupa pelatihan dan pendampingan yang dilakukan dengan mengadopsi langkah-langkah penelitian tindakan melalui empat tahap yaitu perencanaan, pelaksanaan, observasi dan evaluasi serta refleksi. Hasil dari kegiatan ini adalah meningkatnya kemampuan dan keterampilan guru dalam pembuatan dan penerapan alat peraga matematika yang memungkinkan siswa melakukan aktivitas matematika dengan memanfaatkan alat peraga dalam pembelajaran di kelas.
\end{abstract}

Kata kunci: alat peraga, amanuban barat, gugus II, guru SD, matematika

\section{PENDAHULUAN}

Kecamatan Amanuban Barat merupakan salah satu kecamatan di kabupaten Timor Tengah Selatan propinsi Nusa Tenggara Timur. Lokasinya sekitar $12 \mathrm{~km}$ dari kota Soe sebagai ibu kota kabupaten yang merupakan pusat pemerintahan dan pendidikan. Terdapat 23 Sekolah Dasar (SD) yang tersebar di 8 desa dalam kecamatan ini diantaranya SD Inpres Oenali dan SD Inpres Oefatu yang tergabung dengan 5 SD lainnya dalam Gugus II Kecamatan Amanuban Barat. Guru-guru kelas dalam gugus ini tergabung dalam Kelompok Kerja Guru (KKG) Gugus II.

Berdasarkan hasil diskusi dengan beberapa guru dan kepala sekolah di SD Inpres Oefatu maupun kepala SD Inpres Oenali selaku Ketua KKG Gugus II, diperoleh informasi bahwa masih banyak siswa yang sulit belajar matematika karena menganggap matematika sebagai mata pelajaran yang menakutkan dan abstrak. Kenyataan ini sesuai dengan pendapat Rohayati (2012) yaitu hingga saat ini, mata pelajaran matematika di sekolah (termasuk di Sekolah Dasar/SD) masih dianggap sebagai mata pelajaran yang paling sulit di antara mata pelajaran yang lain.
Memang hal yang wajar terutama bagi siswa SD apabila mereka merasa kesulitan dalam mempelajari matematika, karena sifat dari matematika itu sendiri yang berkenaan dengan konsep abstrak, berpola pikir deduktif dan konsisten (Depdiknas, 2010).

Dari hasil wawancara juga diperoleh informasi bahwa dalam pembelajaran matematika guru masih berpaku pada buku teks saja. Siswa lebih banyak mendapat penjelasan secara langsung oleh guru yang didominasi dengan pemberian ceramah dan sangat jarang menggunakan media pembelajaran seperti alat peraga ataupun media-media inovatif berbasis tekonologi lainnya. Siswa diberikan banyak fakta, konsep dan prinsip matematika tetapi jarang dilibatkan dalam proses matematika yaitu terkait bagaimana fakta-fakta tersebut diperoleh. Tentunya pembelajaran seperti ini kurang sesuai dengan tingkat perkembangan berpikir anak SD yang masih pada taraf operasional konkrit (umur 7-11 tahun) dan lambat laun akan membuat siswa bosan.

Media pembelajaran adalah alat yang dapat membantu proses belajar mengajar dan berfungsi untuk memperjelas makna pesan 
yang disampaikan, sehingga dapat mencapai tujuan pembelajaran dengan lebih baik dan sempurna (Annisah, 2014). Kurang tersedianya sarana dan prasarana yaitu media pembelajaran yang bervariasi serta rendahnya pemahaman dan keterampilan guru untuk merancang media pembelajaran matematika yang inovatif berbanding terbalik dengan tuntutan implementasi Kurikulum 2013 dengan pendekatan saintifik yaitu adanya kemampuan siswa dalam visualisasi objek-objek matematika. Akibatnya siswa belajar matematika dengan cara-cara yang kurang bermakna. Siswa cenderung menghafal konsep atau prosedur matematis tertentu dan belajar matematika lebih banyak secara mekanistik. Hal ini berdampak pada rendahnya prestasi belajar matematika yang dicapai siswa. Ratarata hasil belajar siswa belum mencapai Kriteria Ketuntasan Minimal (KKM) yang ditetapkan oleh sekolah.

Pembelajaran matematika di SD merupakan dasar bagi siswa pada jenjang selanjutnya. Jika di SD siswa sudah tidak menyenangi matematika, maka cenderung pada jenjang berikutnya sukar menumbuhkan sikap gemar terhadap matematika. Upaya yang dapat dilakukan adalah menurunkan tingkat keabstrakan matematika dengan menghubungkan konsep matematika yang abstrak menjadi konkrit melalui pengalaman langsung dengan benda nyata. Pengalaman konkrit akan memberikan visualiasi konsep yang jauh lebih bagus. Hal ini sesuai dengan pendapat Bruner (Suherman dkk, 2003:43) bahwa dalam proses belajar jika siswa diberikan kesempatan untuk memanipulasi benda-benda (alat peraga) maka siswa akan melihat langsung bagaimana keteraturan dan pola struktur yang terdapat pada benda yang sedang diperhatikannya. Alat peraga adalah seperangkat benda konkrit yang dirancang, dibuat atau disusun secara sengaja yang digunakan untuk membantu menanamkan atau mengembangkan konsep-konsep serta prinsipprinsip dalam matematika. Alat peraga dapat menyajikan hal-hal yang abstrak dalam bentuk benda-benda atau fenomena-fenomena kongkrit yang dapat dilihat, dipegang, diubahubah sehingga hal-hal yang abstrak lebih mudah dipahami (Yensy, 2012).

Tujuan dari pembelajaran matematika di SD tidak mudah dicapai jika hanya mengandalkan guru sebagai ujung tombak. Diperlukan lingkungan yang kondusif terutama kelengkapan sarana dan prasarana termasuk didalamnya media pembelajaran guna mendukung pembelajaran matematika agar sesuai dengan karakteristik anak SD. Keterbatasan fasilitas dan kurangnya kegiatan pelatihan yang diikuti oleh guru membuat kemampuan guru dalam pembuatan alat peraga masih sangat kurang.

Berdasarkan hasil wawancara dengan guru dan kepala sekolah juga diperoleh informasi bahwa frekuensi keterlibatan guru dalam mengikuti pelatihan tingkat provinsi atau tingkat nasional terkait desain media pembelajaran masih sangat kecil. Oleh karena itu kemampuan guru dalam mendesain alat peraga matematika masih rendah. Pertemuan KKG maupun pelatihan-pelatihan yang dilakukan ditingkat kabupaten selama inipun lebih diarahkan pada kegiatan pembuatan administrasi pembelajaran, dangkal dan belum menyentuh pada esensi dari pembelajaran matematika seperti desain alat peraga.

Pengadaan alat peraga merupakan kebutuhan yang mendesak. Memperhatikan kondisi sekolah yang jauh dari jangkauan pusat kota dan kurangnya kegiatan pelatihan yang diikuti oleh guru khususnya dalam pembuatan alat peraga matematika maka disepakati solusi dari prioritas persoalan yang ada yaitu transfer ipteks berupa pendampingan pembuatan dan penerapan alat peraga matematika bagi guru SD gugus II kecamatan Amanuban Barat.

\section{METODE KEGIATAN}

Metode pelaksanaan kegiatan ini berupa pelatihan dan pendampingan yang dilakukan dengan mengadopsi langkahlangkah penelitian tindakan model Lewin yang terdiri dari 4 (empat) tahapan, yaitu: perencanaan, tindakan, observasi dan evaluasi, serta refleksi (Iskandar, 2011:28). Tahap perencanaan berupa penyusunan jadwal kegiatan pelatihan dan pendampingan serta persiapan alat dan bahan penunjang kegiatan.

Tindakan dalam kegiatan ini berupa pelatihan bagi guru-guru tentang desain alat peraga matematika dalam pembelajaran matematika SD serta pendampingan bagi guruguru dalam produksi dan penerapan alat peraga tersebut dalam pembelajaran matematika di kelas.

Observasi dilakukan terhadap proses pembuatan dan penerapan alat peraga matematika oleh para guru mitra. Instrumen yang digunakan berupa catatan lapangan. Beberapa hal yang diobservasi adalah kendalakendala, kekurangan-kekurangan, dan kelemahan-kelemahan yang muncul dalam proses pembuatan maupun dalam penerapan 
alat peraga. Evaluasi dilakukan terhadap kuantitas dan kualitas produk alat peraga matematika yang dihasilkan. Refleksi dilakukan terhadap kegiatan yang telah dilaksanakan untuk mengetahui kekurangankekurangan atau kelebihan-kelebihan terhadap kegiatan-kegiatan yang telah dilakukan dalam rangka untuk menetapkan rekomendasi terhadap keberlangsungan atau pengembangan kegiatan-kegiatan berikutnya.

\section{HASIL \& PEMBAHASAN}

Kegiatan pengabdian ini dilaksanakan pada bulan juli 2018 yang melibatkan 50 guru yang terdiri dari guru-guru SD Inpres Oenali dan SD Inpres Oefatu sebagai sekolah mitra dan guru-guru 5 SD lainnya yang tergabung dalam gugus II kecamatan Amanuban Barat sebagai sekolah imbas. Kegiatan diawali dengan penyampaian materi tentang manfaat dan pentingnya penggunaan alat peraga dalam pembelajaran matematika SD, pelatihan pembuatan alat peraga matematika dan dilanjutkan dengan pendampingan penerapan alat peraga tersebut.

Penyampaian Materi tentang Pentingnya Alat Peraga dalam Pembelajaran Matematika SD

Pemberian materi terkait inovasi pembelajaran dan manfaat serta pentingnya penggunaan alat peraga matematika dalam pembelajaran matematika bertujuan untuk meningkatkan pengetahuan dan motivasi guru dalam pembuatan alat peraga. Guru-guru sangat antusias dengan pemaparan materi yang diberikan sehingga banyak pertanyaan yang diajukan dalam sesi diskusi setelah pemaparan materi.

Pelatihan pengenalan dan pembuatan alat peraga matematika

Kegiatan dilanjutkan dengan pengenalan dan cara pembuatan alat peraga matematika yaitu mistar hitung, papan hitung, timbangan angka, papan paku, berbagai bangun datar seperti persegi panjang, segitiga, persegi, jajargenjang, trapesium, belah ketupat dan layang-layang serta bangun ruang seperti kubus dan balok yang telah disiapkan terlebih dahulu oleh tim pengabdian sebagai contoh kepada guru-guru. Setelah guru-guru dikenalkan dengan alat peraga yang ada kemudian dilanjutkan dengan pelatihan pembuatan alat peraga tersebut.

Guru-guru dibagi dalam beberapa kelompok untuk kemudian mulai mengerjakan satu jenis alat peraga menggunakan alat dan bahan yang telah disediakan oleh tim. Guru diberikan kebebasan untuk mendesain alat peraga menurut kreatifitasnya. Setelah proses pembuatan selesai perwakilan setiap kelompok mempresentasikan cara dan tujuan pembuatan alat peraga yang telah dibuat tersebut.

Kegiatan pelatihan ini mendapat respon yang sangat positif dari guru (peserta) yang ditandai dengan keaktifan setiap anggota kelompok untuk memproduksi alat peraga yang menjadi tanggung jawabnya. Guru-guru bersemangat menunjukkan kreatifitasnya dalam memproduksi alat peraga serta terlibat aktif menanggapi hasil kerja kelompok lain saat presentasi dan diskusi.

Pendampingan penerapan alat peraga matematika

Tahapan ini dimulai dari penjelasan tim pengabdian terkait penggunaan setiap alat peraga matematika yang telah disiapkan sebelumnya maupun yang baru dibuat oleh para guru. Tim dosen menjelaskan cara penyampaian konsep matematika yang bersesuaian dengan alat peraga yang digunakan. Selanjutkan setiap guru kembali dalam kelompok untuk mendiskusikan pengunaan setiap alat peraga yang dibagikan dalam kelompoknya untuk kemudian dipresentasikan penerapannya dalam pembelajaran di kelas.

Pada tahapan ini respon guru juga sangat positif yaitu guru terlibat aktif dalam menjelaskan materi matematika menggunakan alat peraga yang telah dikerjakan oleh kelompok masing-masing. Antusiasme guru juga terlihat saat penjelasan oleh perwakilan dari setiap kelompok atas hasil kerja yang telah dibuat dengan banyaknya pertanyaan yang dilontarkan oleh kelompok lain mengenai bagaimana penggunaannya dan untuk materi apa saja yang dapat digunakan sebagai alat bantu untuk penanaman konsep matematika.

Berikut beberapa gambar tentang kegiatan pengabdian. 


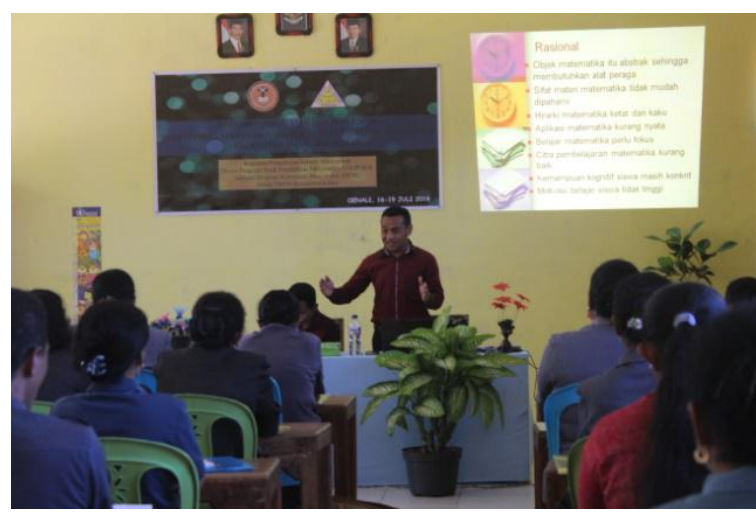

Gambar 1. Penyampaian Materi

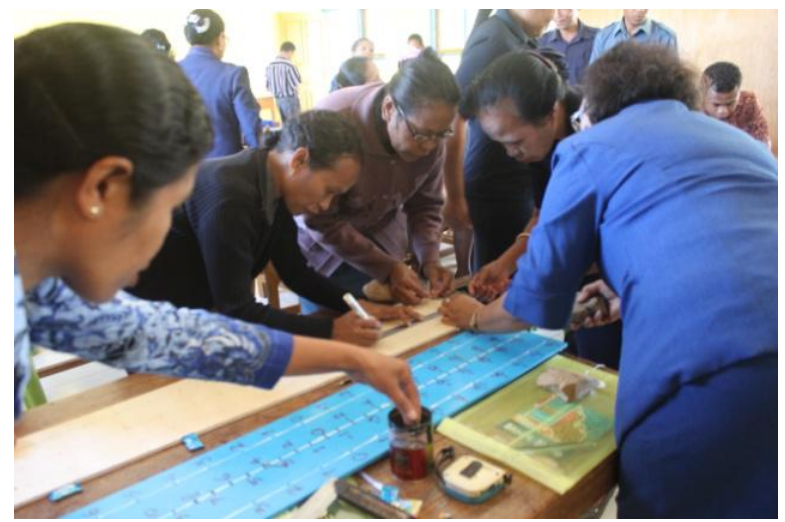

Gambar 3. Membuat Papan Hitung

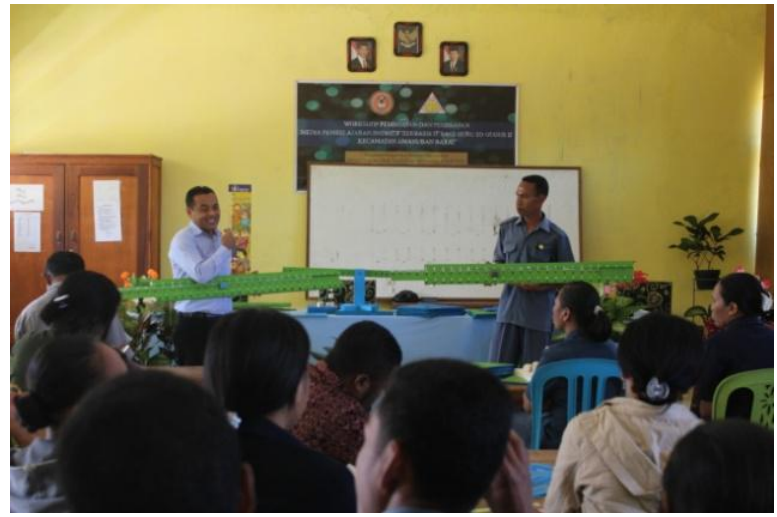

Gambar 5. Mempresentasikan Penggunaan Mistar Hitung

Melalui kegiatan pengabdian masyarakat ini para peserta (guru-guru SD gugus II Amanuban Barat) menjadi paham bagaimana merancang dan memanfaatkan media belajar untuk menanamkan konsep kepada siswa. Media yang disiapkan berupa alat peraga sebagai alat bantu dalam pembelajaran agar pembelajaran menjadi menyenangkan, tidak abstrak, mudah dimengerti, bervariasi serta lebih variatif dalam memvisualisasikannya. Sebagaimana Suherman, dkk (2003:242) mengemukakan bahwa untuk memahami konsep abstrak, anak memerlukan benda-benda kongkrit (riil) sebagai perantara atau visualisasinya.

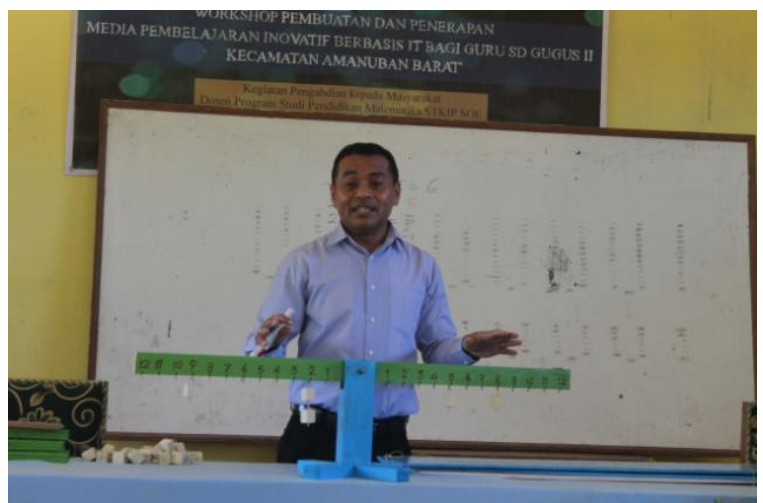

Gambar 2. Penjelasan Pembuatan dan Penggunaan Alat Peraga oleh Tim

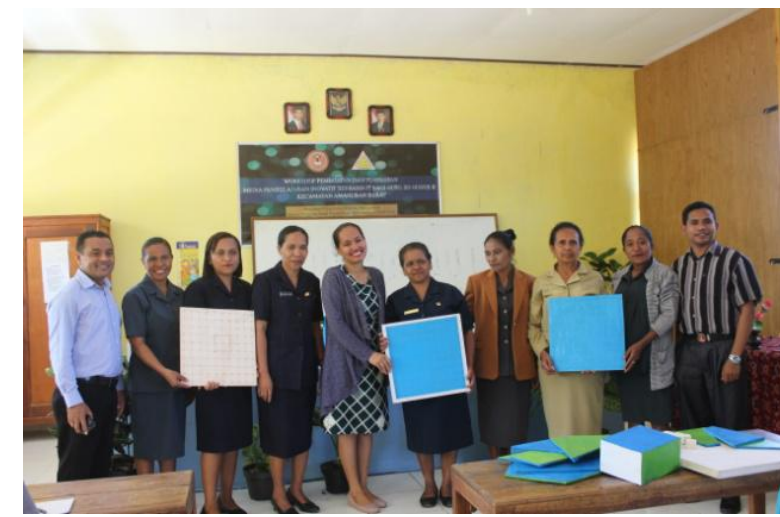

Gambar 4. Hasil Pembuatan Papan Paku

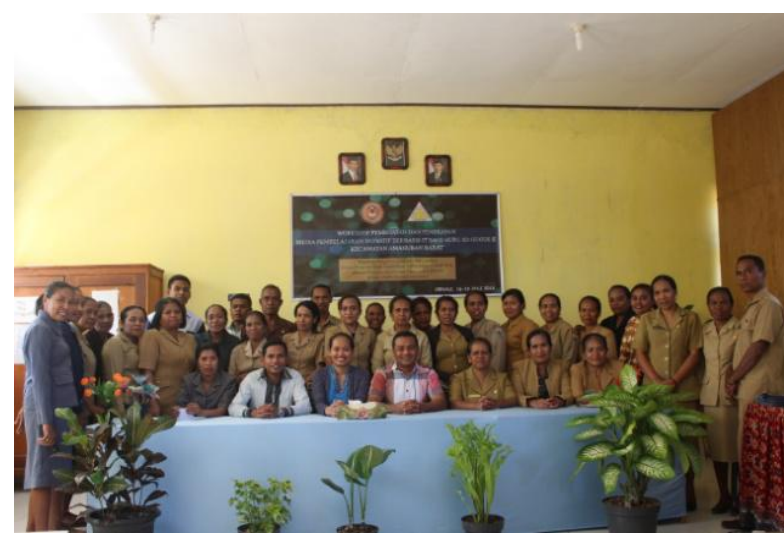

Gambar 6. Tim Pengabdian bersama Para Peserta

Penggunaan alat peraga mistar hitung dan papan hitung memudahkan para guru dalam menanamkan konsep berhitung pada peserta didik. Para guru meyakini bahwa siswa akan menjadi lebih mengerti konsep berhitung bilangan bulat ketika menggunakan alat peraga mistar hitung atau papan hitung.

Materi geometri seperti bangun datar dan bangun ruang yang diajarkan pada siswa SD gugus 2 Amanuban Barat selama ini juga tanpa menggunakan alat peraga sehingga melalui pembuatan dan penggunaan papan berpaku, bangun-bangun datar dan ruang sangat memudahkan dalam pengajaran serta konsep akan lebih mudah dipahami oleh siswa. 
Metode pengajaran menggunakan alat peraga ini memfasilitasi siswa untuk melihat secara nyata bentuk bangun yang ada serta memanupilasinya untuk menentukan rumus keliling dan luas dari bangun datar maupun luas permukaan dan volume bangun ruang tersebut. Hal ini mampu mengembangkan kemampuan berpikir anak seperti yang dikemukakan oleh Van Hiele yaitu tiga unsur utama dalam pengajaran geometri yaitu waktu, materi pengajaran dan metode pengajaran yang diterapkan, jika ditata secara terpadu akan meningkatkan kemampuan berpikir anak kepada tingkatan berpikir yang lebih tinggi (Suherman dkk, 2003:51).

Penggunaan alat peraga dalam pembelajaran berupa mistar hitung, papan hitung, timbangan angka, papan paku, berbagai bangun datar seperti persegi panjang, segitiga, persegi, jajargenjang, trapesium, belah ketupat dan layang-layang maupun bangun ruang seperti kubus dan balok sebagai media dalam pembelajaran matematika memudahkan siswa untuk memahami konsep materi yang disampaikan, oleh karena itu guru harus kreatif dalam menyiapkan pembelajaran. Sebagaimana yang dikemukakan oleh Istiani dan Arnidha (2018) yakni dalam pengajaran matematika di SD diperlukan alat peraga agar memudahkan siswa dalam memahami materi sehingga kreatifitas guru dalam kegiatan belajar mengajar sangat dibutuhkan.

Hasil dari kegiatan pengabdian ini adalah meningkatkan kreatifitas guru dalam mempersiapkan media yang sesuai dengan materi pembelajaran, meningkatkan pemahaman guru mengenai bagaimana menggunakan alat peraga dengan baik, serta meningkatnya kesadaran dan pemahaman guru untuk berinovasi dalam pembelajaran.

\section{KESIMPULAN \& SARAN}

Kegiatan pengabdian yang telah dilaksanakan merupakan bentuk transfer ipteks kepada guru-guru. Melalui kegiatan ini kemampuan dan keterampilan guru dalam pembuatan serta penerapan alat peraga, kesadaran dan pemahaman guru untuk berinovasi dalam pembelajaran matematika meningkat sehingga memungkinkan siswa melakukan aktivitas matematika dengan memanfaatkan alat peraga dalam pembelajaran di kelas.

Peserta yang telah mengikuti kegiatan ini diharapkan terus mengembangkan kemampuan, keterampilan dan kreatifitasnya dalam membuat dan menerapkan alat peraga untuk materi matematika yang lain sehingga pembelajaran matematika di SD menjadi lebih konkrit, semakin berkualitas dan menyenangkan bagi siswa.

\section{DAFTAR PUSTAKA}

Annisah, S. (2014). Alat Peraga Pembelajaran Matematika. Tarbawiyah, 11(1),1-15.

Depdiknas. (2010). Pedoman Pembelajaran Matematika di Sekolah Dasar. Jakarta: Direktorat Pembinaan Taman Kanak-kanak dan Sekolah Dasar.

Iskandar. (2011). Penelitian Tindakan Kelas. Jakarta: Gaung Persada Press.

Istiani, A. \& Arnidha, Y. (2018). Pendampingan Pembuatan dan Penggunaan Alat Pegara Dakota pada Pembelajaran FPB dan KPK. Publikan, 8(1), 66-70.

Rohayati, A. (2012). Alat Peraga Pembelajaran Matematika. Bandung: UPI.

Suherman, H. E., dkk. (2003). Strategi Pembelajaran Matematika Kontemporer. Bandung: UPI.

Yensy, N. A. (2012). Penerapan Model Pembelajaran Kooperatif Tipe Examples Non Examples dengan Menggunakan Alat Peraga untuk Meningkatkan Hasil Belajar Siswa di Kelas VIII SMPN 1 Argamakmur. Exacta, X(1), 24-35. 